\title{
Advances in European agroforestry: results from the AGFORWARD project
}

\author{
Paul J. Burgess $\mathbb{D} \cdot$ Adolfo Rosati
}

Received: 30 April 2018/Accepted: 28 May 2018/Published online: 9 June 2018

(C) The Author(s) 2018

\begin{abstract}
In global terms, European farms produce high yields of safe and high quality food but this depends on the use of many off-farm inputs and the associated greenhouse gas emissions, loss of soil nutrients and other negative environmental impacts incur substantial societal costs. Farmers in the European Union receive support through a Common Agricultural Policy (CAP) that comprises direct payments to farmers (Pillar I) and payments related to rural development measures (Pillar II). This paper examines the ways in which agroforestry can support European agriculture and rural development drawing on the conclusions of 23 papers presented in this Special Issue of Agroforestry Systems which have been produced during a 4-year research project called AGFORWARD. The project had the goal of promoting agroforestry in Europe and focused on four types of agroforestry: (1) existing systems of high nature and cultural value, and agroforestry for (2) high value tree, (3) arable, and (4) livestock systems. The project has advanced our understanding of the extent of
\end{abstract}

P. J. Burgess $(\bowtie)$

Cranfield University, Cranfield, Bedfordshire MK43 0AL, UK

e-mail: p.burgess@cranfield.ac.uk

A. Rosati

Consiglio per la Ricerca in Agricoltura e l'Analisi dell'Economia Agraria, Centro di Ricerca Olivicoltura, Frutticoltura e Agrumicoltura, CREA OFA, Via Nursina, 2, Spoleto, PG, Italy agroforestry in Europe and of farmers' perceptions of agroforestry, including the reasons for adoption or non-adoption. A participatory approach was used with over 40 stakeholder groups across Europe to test selected agroforestry innovations through field trials and experiments. Innovations included improved grazing management in agroforestry systems of high nature and cultural value and the introduction of nitrogen fixing plants in high value timber plantations and olive groves. Other innovations included shelter benefits for arable crops, and disease-control, nutrientretention, and food diversification benefits from integrating trees in livestock enterprises. Biophysical and economic models have also been developed to predict the effect of different agroforestry designs on crop and tree production, and on carbon sequestration, nutrient loss and ecosystems services in general. These models help us to quantify the potential environmental benefits of agroforestry, relative to agriculture without trees. In view of the substantial area of European agroforestry and its wider societal and environmental benefits, the final policy papers in this Special Issue argue that agroforestry should play a more significant role in future versions of the CAP than it does at present.

Keywords Europe $\cdot$ Research · Innovation · Land use $\cdot$ Agriculture $\cdot$ Forestry 


\section{Introduction}

The European Union is home to 508 million people (about $7 \%$ of the world's population) and covers 4.5 million $\mathrm{km}^{2}$ (about $3 \%$ of the global total). In common with other regions of the world, European governments have signed up to the Sustainable Development Goals which seek to balance the improvement of human prosperity with the maintenance and improvement of the environment (United Nations 2015).

Numerous studies have highlighted the global need to increase food production whilst reducing the environmental costs (e.g. Foresight 2011; FAO 2014). As demonstrated by Chatterton et al. (2015), many of the production systems in Europe are successful in providing high value products, but often at a cost to regulating services, such as the release of greenhouse gases and loss of soil nutrients, or cultural services such as landscape aesthetics and biodiversity (Fig. 1). In common with many regions, the goal of European policy makers and land managers should be to maintain or improve the value of agricultural production whilst reducing the socio-environmental costs or in fact increasing the social and environmental benefits; a process that has been termed "sustainable intensification" (Garnett et al. 2013).

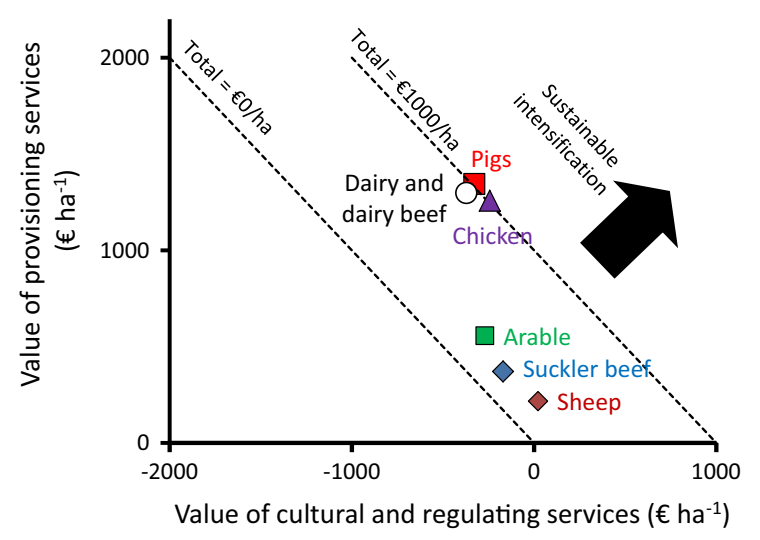

Fig. 1 Annual value of provisioning services (y-axis) and cultural and regulating services (x-axis) of six UK farm systems (after Chatterton et al. 2015; assumption of $1.14 €=1.00 £$ ). The combination of services creating similar combined values can be viewed as diagonal lines. One aim in promoting agroforestry, the integration of trees with farming, is to increase or maintain the value of production whilst enhancing cultural and regulating services
The development of agriculture within the EU occurs within the Common Agricultural Policy which is monitored, according to Regulation 1306/2013, in terms of "(a) viable food production, with a focus on agricultural income, agricultural productivity and price stability; (b) sustainable management of natural resources and climate action, with a focus on greenhouse gas emissions, biodiversity, soil and water, and (c) balanced territorial development, with a focus on rural employment, growth and poverty in rural areas" (European Union 2013). In other words, the European rural land use policy seeks to achieve economic, environmental, and social objectives.

Agriculture is the dominant use for about $40 \%$ of the EU's land area, with another $20 \%$ also belonging to farms in the form of "wooded" areas (Eurostat 2017a). Arable land (including temporary grassland) accounts for about $60 \%$ of the utilised agricultural area, with $33 \%$ used for permanent grassland, $6.6 \%$ for permanent crops (e.g. olives, vineyards, and fruit trees), and $0.4 \%$ for homegardens (Eurostat 2017a). In 2013, it was estimated that 22.8 million people were directly employed on farms, but the majority of these were employed on a part-time basis. When expressed in terms of a full-time equivalent, the number of people employed on farms in the EU-28 is about 9.5 million (Eurostat 2017a). As there are about 10.8 million farms, then on average a farm in the EU employs less than one person. However such averages do not describe the distribution. The smallest $70 \%$ of farms account for only $5 \%$ of the off-farm output, whilst the largest $6.3 \%$ of farms produce $71 \%$ (Eurostat 2017b).

About $40 \%$ of the European population lives in cities ( $>50,000$ inhabitants and with more than 1500 inhabitants per $\mathrm{km}^{2}$ ), $32 \%$ in towns and suburbs (> 5000 inhabitants and with more than 300 inhabitants per $\mathrm{km}^{2}$ ), and $28 \%$ in rural areas (Eurostat 2017a). Both urban and rural areas face common challenges such as poverty and the need to counteract climate change. However there are also differences. The attractions of cities include employment and education opportunities, but the disadvantages include high living costs and air pollution. The attractions of living in rural areas include lower living costs, more space, greater access to nature, and less pollution. However there are also costs such as fewer education and employment opportunities and reduced transport and broadband. In order to address some of these 
factors, the European Union has a Rural Development Policy which forms a second Pillar within the Common Agricultural Policy. In recent years, an increasing proportion of people in Europe are opting to live in towns and suburbs rather than cities or rural areas, as such areas can combine the opportunities of cities and the benefits of rural areas (Eurostat 2017a). In fact, this paper proposes that agroforestry offers a similar "middle" way between forestry and agriculture.

This Special Issue examines the way in which agroforestry in Europe is supporting both agricultural and rural development. Between 2014 and 2017, through a project called AGFORWARD (AGroFORestry that Will Advance Rural Development), funded by the European Commission contract 613520, 80 researchers came together from across Europe to promote the use of agroforestry (Burgess et al. 2018). The project had four broad objectives. These were (1) to examine the extent of agroforestry in Europe and the factors determining uptake, (2) to identify, develop and field-test agroforestry innovations through participatory networks, (3) to evaluate innovative designs and practices at field-, farm-, and landscape-scales, and (4) to promote agroforestry in Europe through policy development and dissemination (Burgess et al. 2015; Fig. 2).

In the description of work for the project, agroforestry was defined as "the practice of deliberately integrating woody vegetation (trees or shrubs) with crop and/or animal systems to benefit from the resulting ecological and economic interactions". Although this definition covers forest farming and home garden systems, the focus of the project was on

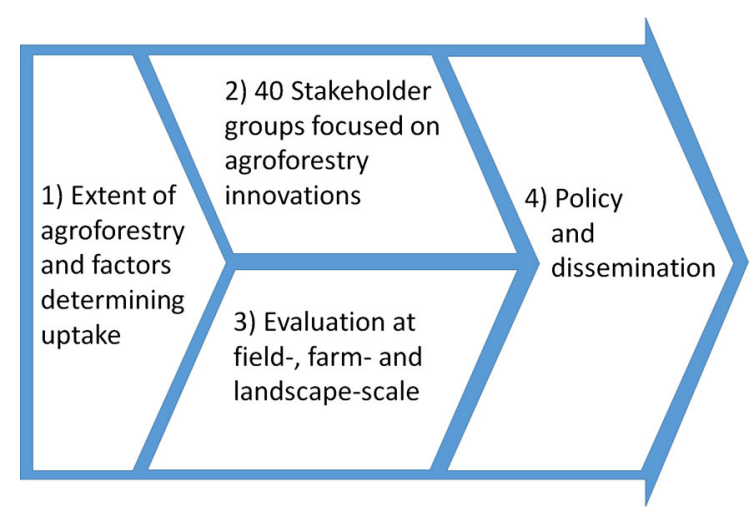

Fig. 2 The AGFORWARD project had four broad objectives to achieve the overall goal of the promotion of agroforestry in Europe agroforestry on agricultural land and therefore the project focussed silvopastoral, silvoarable, and hedge, windbreak and riparian buffer strip systems. This Special Issue includes 23 papers derived from the project.

\section{Extent of agroforestry and factors determining uptake}

In a similar way that there has been an "urban" and "rural" divide in rural development literature, there has also been an "agricultural" and "forestry" divide in land use studies. However there are new datasets which allow administrators to monitor the integration of trees and shrubs with agriculture. Den Herder et al. (2017) used the 2012 LUCAS land use and cover dataset, which records multi-functional land use, to examine the extent of agroforestry in Europe. Focusing on the combination of trees with agriculture, they calculated an area of 15.4 million ha, equivalent to $8.8 \%$ of the agricultural area of the EU-28 and $3.3 \%$ of the total land area. This is substantially higher than values derived from a review of the literature. In addition, Mosquera-Losada et al. (2016) explain that this total excludes 2.7 million hectares of grazed shrubland and 1.8 million hectares of homegardens. In this Special Issue, Santiago-Freijanes et al. (2018) examine the use of the transect data from the LUCAS survey and calculate that the area of lone trees is equivalent to about 300,000 hectares, and the area of hedgerows in Europe is 1.8 million ha. In the future, these estimates can be compared with national estimates, such as the recent calculation of an area of 97,000 ha of lone trees and 159,000 ha of hedgerows in Great Britain (Forestry Commission 2017). The use of such datasets allows administrators and land use planners to monitor the extent of agroforestry across Europe. The European analysis also showed that the highest proportions of agroforestry occurred in the Mediterranean areas.

One of the observations from working in different parts of Europe is that what people consider as modern agroforestry in one location, may be considered as common practice in another. For example, on the flat arable areas reclaimed from wetlands in North-East Italy the integration of $400 \mathrm{~m}$ tree lines along drainage ditches spaced at intervals of $90 \mathrm{~m}$ is considered agroforestry and results in "fields" of about 3.6 ha. By 
contrast the often tree-lined hedgerows in Brittany in North West France results in a median field size of only 1.25 ha (Thenail, C., personal communication 2018 based on 2015 Land Parcel Identification System database) and Britt et al. (2011) report a median field size of 3 ha in Devon in South West England. Hence what is recognised as an "agroforestry" landscape in one region, e.g. North-East Italy, can be viewed as standard agriculture practice in another.

There are many different ways of categorising agroforestry systems, and the most appropriate method depends on the purpose of the categorisation (Nair 1993). In the AGFORWARD project the focus was on the promotion of agroforestry. Hence the categorisation focused on three extreme typologies of farm type: farms focused on (1) arable production, (2) livestock production, and (3) high value trees. In the first two examples, agroforestry implies the integration of trees and/or shrubs. In the high value tree systems, agroforestry implies the integration of intercrops or grazing. In addition to these three starting points, there are areas where agroforestry already exists, and we termed such systems, which include wood pasture and hedgerow systems, "agroforestry of high nature and cultural value" (Fig. 3).

Rois-Díaz et al. (2018) examine the perspective of farmers on the potential benefits and costs of

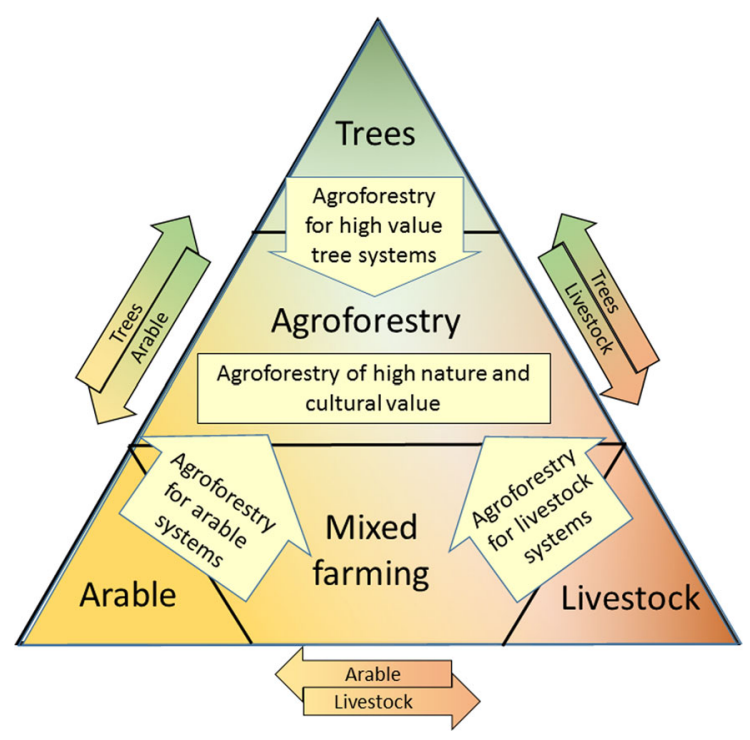

Fig. 3 In the context of promoting agroforestry, the four types of agroforestry considered in the AGFORWARD project were: existing agroforestry systems of high nature and cultural value, and agroforestry for high value tree, arable, or livestock systems agroforestry practices, based on an analysis of 183 farmer interviews in 14 case study systems in eight European countries. The study highlights that although farmers were integrating trees with crops and/or livestock, they did not always recognise the term "agroforestry". The most important drivers in determining whether a farmer practiced agroforestry included whether it was a tradition in the family, the capacity to learn from others, and the benefits of diversifying farm outputs. The study indicated that younger farmers, those with greater income diversity, and holdings with high tourism potential were more likely to implement agroforestry than older farmers, and farmers on specialised farms and holdings with low tourism potential.

García de Jalón et al. (2018a) examine the positive and negative perceptions of 344 stakeholders from across Europe in relation to four types of agroforestry described in Fig. 3. Improved biodiversity and wildlife habitats, animal health and welfare, and landscape aesthetics were seen as the main positive aspects of agroforestry. By contrast, increased labour, complexity of work, management costs and administrative burden were seen as the most important negative aspects. Overall, improving the environmental value of agriculture was seen as the main benefit of agroforestry, whilst management and socio-economic issues were seen as the most important barriers. The third paper related to the uptake of agroforestry focuses specifically on the situation in Italy (Camilli et al. 2018). As described by García de Jalón et al. (2018a), the effects of agroforestry on production and the environment were generally perceived as positive, whilst those related to management were generally negative. The process of bringing the groups together seems to be an effective means for identifying the key research gaps that need to be addressed to promote agroforestry.

Lovrić et al. (2018) argue that in many marginal rural areas, farmers believe that agroforestry is the most appropriate land use as the poor quality of the land means that intensive monoculture systems are particularly unsustainable. Lovrić et al. therefore determined how different determinants affect uptake of alternative agroforestry practices in the Mediterranean region, based on quantitative inputs from agroforestry experts, which were used to develop a multi-criteria decision making model using an analytical network process (ANP). Using the four types of 
agroforestry systems (described in Fig. 1) and a noagroforestry option, high nature and cultural value agroforestry was ranked most highly. Family tradition, product diversification, and lower use of pesticides were identified as the most important determinants for the uptake of agroforestry in the Mediterranean region.

\section{Innovations in agroforestry practice}

Within the AGFORWARD project, 40 stakeholder groups (involving about 820 stakeholders across 13 European countries) developed and field-tested agroforestry innovations within participative research and development networks focused on the four types described in Fig. 3. While detailed results are reported in the papers of this Special Issue, a summary of the main results and conclusions is presented below.

Agroforestry of high nature and cultural value: Moreno et al. (2018) describe the main products and services derived from agroforestry systems of high nature and cultural value. Although some of the traditional practices and products have been abandoned, many of the studied systems continue to provide multiple woody and non-woody plant products and high-quality food from livestock and game. Compared to conventional agriculture and forestry, these systems are particularly valued in terms of their biodiversity and regulating ecosystem services. The systems can reduce fire risk, compared to conventional forestry, and increase carbon sequestration, moderate the microclimate, and reduce soil erosion and nutrient leaching compared to conventional agriculture. Although some cultural value is captured through tourism and local events, there is a need to more fully translate the positive social and environmental benefits into market prices for the products and services.

Three of the studied innovations were cheaper methods of tree protection, guidance for grazing management, and the establishment of legumes. In Sardinia in Italy, Seddaiu et al. (2018) examined the effect of trees in a wood pasture on pasture production, pasture utilisation rate, biodiversity and soil carbon over three years. In the main growth period (in the spring), pasture production was greater beyond tree canopies than under tree canopies, but greater beneath the trees (compared to beyond the trees) in two winters out of three. The study also indicates that the soil organic carbon content in the $0-40-\mathrm{cm}$ soil layer was greater below the trees. The study suggests that whilst removing the trees may increase overall grass production, this would be at the cost of plant diversity, soil fertility, and winter forage production. Also in Sardinia, Franca et al. (2018) examined the effects of grazing exclusion and environmental conditions on the soil seed bank of a Mediterranean grazed oak wood pasture. They concluded that the size of the persistent seed bank increased with rainfall, grazing, and the available phosphorus content of the soil. Specific site by site grazing regimes could increase the abundance of legumes in the soil seed bank and the species richness and diversity of the understorey vegetation.

One specific agroforestry system of high nature and cultural value is Valonia oak agroforestry as found in Greece. Pantera et al. (2018b) describe the long history, the extent, structure, ecology, products and services of such systems. They argue that the sustainability of the agroforestry system is enhanced through the sale of traditional and new products, eco- and agritourism, and engagement with local stakeholders.

One of the largest agroforestry systems in Europe, in terms of area, is reindeer husbandry in northern Sweden, Norway and Finland which occurs alongside forestry, hunting, and tourism (Valinger et al. 2018). One innovation in reindeer management has been the use of GPS collars to track the reindeer, and adaptive forest management (i.e. forest management adapted to benefit reindeer). The study by Valinger et al. (2018) shows that GPS tracking improved reindeer monitoring but the financial costs were greater than the financial benefits, and that adaptive forest management could increase the gross value added by reindeer husbandry by about a third.

Agroforestry within high value tree systems: Pantera et al. (2018a) describe some of the innovations examined in the AGFORWARD related to the intercropping or grazing of apple orchards, olive and orange groves, chestnut woodlands, and walnut plantations. Even with agroforestry, the primary objective of the farmer is likely to remain the value of tree products like apples, olives, oranges, nuts, or high value timber. Innovations included the use of nitrogenfixing, medicinal, or new food crops between olive trees, orange trees, or high value timber plantations. The introduction of pigs in chestnut orchards in Spain, or sheep in high-stem apple orchards in the United Kingdom and France provide an additional source of 
feed and an ecological way of controlling pasture growth.

Agroforestry for arable systems: Inurreta-Aguirre et al. (2018) describe the effects of trees in Southern France on the yield components, phenology, and canopy characteristics of durum wheat. Twelve varieties of durum wheat were examined within alley cropping experiments beneath 16-year-old poplars in 2015 or 21-year-old ash trees in 2016. The durum wheat yields in both the alley cropping and control conditions were very low $(<10 \%$ of the long-term average) in 2015. In 2016, the reduction in grain yield in the agroforestry system (compared to full sun conditions) was related to a reduced number of grains per ear. The presence of tree delayed the maturity of the crop, and the use of thermal time alone was not sufficient to explain the delay.

Agroforestry for livestock systems: one of the major innovations in the project was a focus on the use of tree fodder in livestock production. For example Luske and van Eekeren (2018) examined the potential of using ash, alder and willow trees as fodder for livestock during summer in the Netherlands. In terms of digestible organic matter, the leaves of ash $(71 \%)$ showed greater value than the leaves of alder and willow (61\%); the equivalent value for grass was $66 \%$. The alder leaves had a higher level of crude protein $(20 \%)$ than the leaves of ash (17\%) and grass (12\%).

One of the benefits of integrating trees in livestock systems is the potential to better retain nutrients, such as nitrogen, within the system rather than losing it through leaching beyond the root zone. Jørgensen et al. (2018) studied the effect of integrating short rotation willow coppice and miscanthus within a freerange pig system in Denmark. They calculated mean nitrogen surpluses of $185 \mathrm{~kg} \mathrm{~N} \mathrm{ha}^{-1}$ and $626 \mathrm{~kg} \mathrm{~N} \mathrm{ha}^{-1}$ for free-range pigs kept at high $\left(117 \mathrm{~m}^{2} / \mathrm{pig}\right)$ and low $\left(360 \mathrm{~m}^{2} / \mathrm{pig}\right)$ densities respectively. At the high population density, uneven ranging and defaecation behaviour by the free-range pigs led to nitrogen "hotspots". However at the low pig population density, the nitrogen surplus was similar to unfertilised grassland and less than that normally seen in free-range pig production.

Bestman et al. (2018) examined the effect of woody vegetation on the risk of avian influenza in free-range poultry production in the Netherlands, which is spread by "high risk" birds. More high-risk birds were observed in free-range areas with less than 5\% woody cover (compared to areas with more woody cover) and in the surroundings of free-range areas in open landscapes (compared to half open landscapes). In the last paper focused on agroforestry for livestock Westaway et al. (2018) discuss possible options for maintaining and recreating an understorey sward beneath trees in poultry systems. The establishment of new swards required a period of exclusion of the poultry and maintenance of the sward was dependent on maintaining poultry numbers below a critical level.

\section{Evaluation at field-, farm- and landscape scale using models}

Whilst some agroforestry innovations can be evaluated within the time-frame of a 4 year project, evaluating the expected effects of different tree configurations over a full tree rotation which may last, for example $20-80$ years, can be analysed using computer models. Dupraz et al. (2018) describe the results of using a process-based 3D model of alley cropping to examine the effect of latitude on the response from two tree densities and two tree line orientations. The modelling indicates that even at high latitudes, crops planted within an alley-cropping system can receive substantial levels of solar radiation. Solar radiation receipt by the understorey crops was maximised by North-South tree lines at high latitudes and East-West tree lines at low latitudes. At medium latitudes, North-South tree lines are indicated as the preferred option to achieve the most homogeneous irradiance of the crop in the alley.

Agroforestry has distinct benefits in terms of reduced greenhouse gas emissions and sequestering carbon in aboveground woody biomass. Although agroforestry can increase soil carbon contents relative to arable cropping, the effects of tree planting in pasture are mixed and often negative (Guo and Gifford 2002). Fornara et al. (2018) examined the effects of trees on the soil carbon of a 26 year old silvopastoral, woodland, and pasture treatments in Northern Ireland. After 26 years, the soil $\mathrm{C}$ (and N) stocks $(0-20 \mathrm{~cm}$ depth) did not significantly vary between the three land uses, but a higher level of carbon was held in more recalcitrant micro-aggregate and silt and clay fractions, which could be more resilient to environmental change, in the plots with trees, compared to the grassland only sites. The effects of trees on soil carbon 
are also examined by Palma et al. (2018) who describe how they modified the Yield-SAFE computer model of tree and crop yields to incorporate the RothC model of soil carbon dynamics. The new algorithms include the calculation of the input of plant material into soil (i.e. leaf fall and root mortality), and initial results suggest that the combined model provides predictions consistent with observed data for a cork oak system in South Portugal and a poplar system in the UK.

The desirability of agroforestry can be considered from both a farmer's immediate financial perspective and a wider societal perspective that includes environmental costs and benefits. Using a case study of an arable crop rotation, a poplar plantation, and a silvoarable system in the United Kingdom, García de Jalón et al. (2018b) describe the use of the Yield-SAFE biophysical model to predict crop and tree yields over a period of 30 years, and the effects on carbon sequestration, greenhouse gas emissions, nitrogen and phosphorus surplus, and soil erosion losses by water. It is possible to derive indicative monetary values for these effects. On the basis of the stated assumptions, the arable option was the most financially profitable system but silvoarable agroforestry provided the greatest societal benefit if the environmental externalities were included. This suggests that the appropriate integration of trees in arable land can provide greater well-being benefits to society overall, than arable farming without trees, or forestry systems on their own. However the authors also highlight that farmers are unlikely to integrate trees, unless the societal benefits can be somehow cashed by the farmers, suggesting the need for policy intervention.

One of the questions examined within the AGFORWARD project was how may the wider uptake of agroforestry affect provisioning and regulating ecosystem services at scales larger than a farm. Kay et al. (2018) examined the ecosystem services provided by agroforestry and non-agroforestry landscapes in six case study sites across Portugal, Spain, Switzerland, and the United Kingdom. The modelling exercise indicated that groundwater recharge was greater in the non-agroforestry than the agroforestry landscapes. By contrast regulating services such as nutrient retention, soil conservation, climate regulation, and pollination, together with habitat richness were all greater in the agroforestry than the non-agroforestry landscapes. The modelled benefits in terms of regulating services are similar to the positive perception of agroforestry for environmental services reported by García de Jalón et al. (2018b).

\section{Policy}

The last three papers of the Special Issue focus on the role of policy, and return to some of the contextual analysis discussed in the second section of this paper. As detailed there, the two main mechanisms for farm support in the EU occur within the CAP in the form of direct payments in Pillar I and payments that support rural development in Pillar II. Tsonkova et al. (2018) explain that there are also substantial legal constraints to the uptake of agroforestry in Germany. For example, farmers claiming Pillar I payments in Germany need to subdivide agroforestry areas into area containing trees and areas which do not. Tsonkova et al. (2018) argue that the management of agroforestry would be less bureaucratic if it was possible to register such fields as areas of agroforestry. Santiago-Freijanes et al. (2018) explain that across Europe there is substantial support for the maintenance of lone trees and hedgerows within rural development programmes. However the current difficulties in monitoring the extent and quality of lone trees and hedgerows makes it difficult to establish administratively simple methods of including such landscape features within Pillar I payments.

Mosquera-Losada et al. (2018) provide an overview of the interactions between agroforestry and the CAP. They explain that the direct payments can be received for land supporting crops, permanent pasture, and designated permanent crops, but that farmers can forfeit these direct payments if selected tree species exceed a given density per hectare or a specified level of cover. Within Pillar II, the Rural Development Regulations for the period 2014-2020 includes one specific agroforestry measure (Measure 8.2), but there are another 27 measures that can, in various ways, support agroforestry. Mosquera-Losada et al. argue that the recognition of agroforestry would be increased if the measures were collated together in one place. They also argue that in view of the social and environmental benefits, agroforestry on agricultural land should retain full Pillar I payments, rather than the reduction in current payments when tree density exceeds 100 trees per hectare. 


\section{Conclusions}

International agroforestry projects, such as AGFORWARD, are a significant means of encouraging joined-up thinking and action concerning land use. As a society we need land use systems and practices that can combine the production of marketable crops, livestock, and tree products with the enhancement of the environment. In Europe, there are new data sources, such as LUCAS, that allow the categorisation and monitoring of multiple land use. Within the project, leaflets have been produced on 46 agroforestry innovations (Balaguer et al. 2017). For agroforestry systems of high nature and cultural value, the innovations include the incorporation of legumes, new grazing systems, and the use of GPS technology. There are ways of increasing the revenue within high value tree systems by introducing intercropping or grazing and the shelter provided by trees can also provide yield benefits in some arable systems. The benefits of integrating trees in livestock systems include animal welfare, disease control, nutrient retention, diversification of feed sources, and increased biodiversity. Computer modelling of agroforestry, using validated models, can provide guidance on the short- and long-term benefits of different agroforestry designs in terms of yields, financial impacts, and wider environmental impacts. The analysis reported in this Special Issue indicate that the integration of trees with farming can offer a middle way which combines the production benefits of agriculture with the environmental benefits of forests. In the same way that a higher proportion of the European population is choosing to live in towns and suburbs (in preference to cities and rural areas), agroforestry can offer a similar sweet spot between agriculture and forestry.

Acknowledgements The AGFORWARD project (Grant Agreement No. 613520) was co-funded by the European Commission, Directorate General for Research and Innovation, within the 7th Framework Programme of RTD, Theme 2-Biotechnologies, Agriculture and Food. The views and opinions expressed in this report are purely those of the writers and may not in any circumstances be regarded as stating an official position of the European Commission. We are thankful for the work of the many anonymous reviewers who made the Special Issue possible.

Open Access This article is distributed under the terms of the Creative Commons Attribution 4.0 International License (http:// creativecommons.org/licenses/by/4.0/), which permits unrestricted use, distribution, and reproduction in any medium, provided you give appropriate credit to the original author(s) and the source, provide a link to the Creative Commons license, and indicate if changes were made.

\section{References}

Balaguer F, Waldie K, Van Lerberghe P, Liagre F, Girardin N, Pagella T, Burgess PJ (eds) (2017) Folder for AGFORWARD agroforestry innovation and best practice leaflets. http://www.agforward.eu/index.php/en/Innovation-leaflets. html. Accessed 6 June 2018

Bestman M, de Jong W, Wagenaar J-P, Weerts T (2018) Presence of avian influenza risk birds in and around poultry free-range areas in relation to range vegetation and openness of surrounding landscape. Agrofor Syst. https://doi. org/10.1007/s10457-017-0117-2

Britt C, Tuffnell N, Kirkham F, Roberts A, Sparks T (2011). Hedgerow management: a survey of land managers' and contractors' practices and attitudes. Defra Project BD2117. http://hedgelink.org.uk/cms/cms_content/files/82_defra_ bd2117_hedge_survey_final_report_feb_2012.pdf. Accessed 6 June 2018

Burgess PJ, Crous-Duran J, den Herder M, Dupraz C, Fagerholm N, Freese D, Garnett K, Graves AR, Hermansen JE, Liagre F, Mirck J, Moreno G, Mosquera-Losada MR, Palma JHN, Pantera A, Plieninger T, Upson M (2015). AGFORWARD project periodic report: January to December 2014. Cranfield University: AGFORWARD. http://www.agforward.eu/index.php/en/news-reader/id27-february-2015.html. Accessed 6 June 2018

Burgess PJ, den Herder M, Dupraz C, Garnett K, Giannitsopoulos M, Graves AR, Hermansen JE, Kanzler M, Liagre F, Mirck J, Moreno G, Mosquera-Losada MR, Palma JHN, Pantera A, Plieninger T (2018) AGFORWARD project final report, 28 Feb 2018. Cranfield University: AGFORWARD

Camilli F, Pisanelli A, Seddaiu G, Franca A, Bondesan V, Rosati A, Moreno GM, Pantera A, Hermansen JE, Burgess PJ (2018) How local stakeholders perceive agroforestry systems: an Italian perspective. Agrofor Syst. https://doi.org/ 10.1007/s10457-017-0127-0

Chatterton J, Graves A, Audsley E, Morris J, Williams A (2015) Using systems-based LCA to investigate the environmental and economic impacts and benefits of the livestock sector in the UK. J Clean Prod 86:1-8

den Herder M, Moreno G, Mosquera-Losada RM, Palma JHN, Sidiropoulou A, Santiago Freijanes JJ, Crous-Duran J, Paulo JA, Tomé M, Pantera A, Papanastasis VP, Mantzanas K, Pachana P, Papadopoulos A, Plieninger T, Burgess PJ (2017) Current extent and stratification of agroforestry in the European Union. Agr Ecosyst Environ 241:121-132

Dupraz C, Blitz-Frayret C, Lecomte I, Molto Q, Reyes F, Gosme M (2018) Influence of latitude on the light availability for intercrops in an agroforestry alley-cropping system. Agrofor Syst. https://doi.org/10.1007/s10457-018-0214-x 
European Union (2013) Regulation (EU) No 1306/2013 of the European Parliament and of the Council of 17 December 2013 on the financing, management and monitoring of the common agricultural policy. https://eur-lex.europa.eu/legalcontent/EN/TXT/PDF/?uri=CELEX:32013R1306\&from= en. Accessed 6 June 2018

Eurostat (2017a) Eurostat regional yearbook. http://ec.europa. eu/eurostat/documents/3217494/8222062/KS-HA-17-001EN-N.pdf/eaebe7fa-0c80-45af-ab41-0f806c433763. Accessed 6 June 2018

Eurostat (2017b) Small and large farms in the EU-statistics from the farm structure survey. http://ec.europa.eu/eurostat/ statistics-explained/index.php/Small_and_large_farms_in_ the_EU_-_statistics_from_the_farm_structure_survey. Accessed 6 June 2018

FAO (2014) Building a common vision for sustainable food and agriculture: principles and approaches. http://www.fao. org/3/a-i3940e.pdf. Accessed 6 June 2018

Foresight (2011) The future of food and farming. Final project report. The Government Office for Science, London. https://www.gov.uk/government/publications/future-offood-and-farming. Accessed 6 June 2018

Forestry Commission (2017) Tree cover outside woodland in Great Britain National Forest Inventory. April 2017. https://www.forestry.gov.uk/pdf/FR_Tree_cover_outside_ woodland_in_GB_statistical_report_2017.pdf/\$FILE/FR_ Tree_cover_outside_woodland_in_GB_statistical_report_ 2017.pdf

Fornara DA, Olave R, Burgess PJ, Delmer A, Upson M, McAdam J (2018) Land use change and soil carbon pools: evidence from a long-term silvopastoral experiment. Agrofor Syst. https://doi.org/10.1007/s10457-017-0124-3

Franca A, Re GA, Sanna F (2018) Effects of grazing exclusion and environmental conditions on the soil seed bank of a Mediterranean grazed oak pasture. Agrofor Syst. https:// doi.org/10.1007/s10457-018-0203-0

García de Jalón S, Burgess PJ, Graves A, Moreno G, McAdam J, Pottier E, Novak S, Bondesan V, Mosquera-Losada MR, Crous-Durán J, Palma JHN, Paulo JA, Oliveira TS, Cirou E, Hannachi Y, Pantera A, Wartelle R, Kay S, Malignier N, Van Lerberghe P, Tsonkova P, Mirck J, Rois M, Kongsted AG, Thenail C, Luske B, Berg S, Gosme M, Vityi A (2018a) How is agroforestry perceived in Europe? An assessment of positive and negative aspects among stakeholders. Agrofor Syst. https://doi.org/10.1007/s10457017-0116-3

García de Jalón S, Graves A, Palma JHN, Williams A, Upson MA, Burgess PJ (2018b) Modelling and valuing the environmental impacts of arable, forestry and agroforestry systems: a case study. Agrofor Syst. https://doi.org/10. 1007/s10457-017-0128-z

Garnett T, Appleby MC, Balmford A, Bateman IJ, Benton TG, Bloomer P, Burlingame B, Dawkins M, Dolan L, Fraser D, Herrero M, Hoffmann I, Smith P, Thornton PK, Toulmin C, Vermeulen SJ, Godfray HCJ (2013) Sustainable intensification in agriculture: premises and policies. Science 341(6141):33-34. https://doi.org/10.1126/science.123448

Guo LB, Gifford RM (2002) Soil carbon stocks and land use change: a meta analysis. Glob Change Biol 8:345-360

Inurreta-Aguirre HD, Lauri PE, Dupraz C, Gosme M (2018) Yield components and phenology of durum wheat in a
Mediterranean alley-cropping system. Agrofor Syst. https://doi.org/10.1007/s10457-018-0201-2

Jørgensen U, Thuesen J, Eriksen J, Horsted K, Hermansen JE, Kristensen K, Kongsted AG (2018) Nitrogen distribution as affected by stocking density in a combined production system of energy crops and free range pigs. Agrofor Syst. https://doi.org/10.1007/s10457-018-0200-3

Kay S, Crous-Duran J, Ferreiro-Domínguez N, García de Jalón S, Graves A, Moreno G, Mosquera-Losada MR, Palma JHN, Roces-Díaz JV, Santiago-Freijanes JJ, Szerencsits E, Weibel R, Herzog F (2018) Spatial similarities between European agroforestry systems and ecosystem services at the landscape scale. Agrofor Syst. https://doi.org/10.1007/ s10457-017-0132-3

Lovrić M, Rois-Díaz M, den Herder M, Pisanelli A, Lovrić N, Burgess PJ (2018) Driving forces for agroforestry uptake in Mediterranean Europe: application of the analytic network process. Agrofor Syst. https://doi.org/10.1007/s10457018-0202-1

Luske B, van Eekeren N (2018) Nutritional potential of fodder trees on clay and sandy soils. Agrofor Syst. https://doi.org/ 10.1007/s10457-017-0180-8

Moreno G, Aviron S, Berg S, Crous-Duran J, Franca A, García de Jalón S, Hartel T, Mirck J, Pantera A, Palma JHN, Paulo JA, Re GA, Sanna F, Thenail C, Varga A, Viaud V, Burgess PJ (2018) Agroforestry systems of high nature and cultural value in Europe: provision of commercial goods and other ecosystem services. Agrofor Syst. https://doi.org/10.1007/ s10457-017-0126-1

Mosquera-Losada MR, Santiago Freijanes JJ, Pisanelli A, Rois M, Smith J, den Herder M, Moreno G, Malignier N, Mirazo JR, Lamersdorf N, Ferreiro Domínguez N, Balaguer F, Pantera A, Rigueiro-Rodríguez A, Gonzalez-Hernández P, Fernández-Lorenzo JL, Romero-Franco R, Chalmin A, Garcia de Jalon S, Garnett K, Graves A, Burgess PJ (2016) Extent and success of current policy measures to promote agroforestry across Europe. Deliverable 8.23 for EU FP7 research project: AGFORWARD 613520. 8 Dec 2016, p 95. http://www.agforward.eu/index.php/en/extent-andsuccess-of-current-policy-measures-to-promote-agroforestryacross-europe.html

Mosquera-Losada MR, Santiago-Freijanes JJ, Pisanelli A, Rois M, Smith J, den Herder M, Moreno G, Ferreiro-Domínguez N, Malignier N, Lamersdorf N, Balaguer F, Pantera A, Rigueiro-Rodríguez A, Aldrey JA, Gonzalez-Hernández P, Fernández-Lorenzo JL, Romero-Franco R, Burgess PJ (2018) Agroforestry in the European Common Agricultural Policy. Agrofor Syst. https://doi.org/10.1007/s10457-0180251-5. (accepted)

Nair PKR (1993) An introduction to agroforestry. Kluwer, Dordrecht

Palma JHN, Crous-Duran J, Graves AR, García de Jalón S, Upson M, Oliveira TS, Paulo JA, Ferreiro-Domínguez N, Moreno G, Burgess PJ (2018) Integrating belowground carbon dynamics into Yield-SAFE, a parameter sparse agroforestry model. Agrofor Syst. https://doi.org/10.1007/ s10457-017-0123-4

Pantera A, Burgess PJ, Mosquera-Losada MR, Moreno GM, López-Díaz ML, Corroyer N, McAdam J, Rosati A, Papadopoulos AM, Graves A, Rigueiro Rodríguez A, Ferreiro-Domíguez N, Fernández Lorenzo JL, González- 
Hernández MP, Papanastasis VP, Mantzanas K, Van Lerbergerhe P, Malignier N (2018a) Agroforestry for high value tree systems in Europe. Agrofor Syst. https://doi.org/ 10.1007/s10457-017-0181-7

Pantera A, Papadopoulos A, Papanastasis VP (2018b) Valonia oak agroforestry systems in Greece: an overview. Agrofor Syst. https://doi.org/10.1007/s10457-018-0220-z

Rois-Díaz M, Lovric N, Lovric M, Ferreiro-Domínguez N, Mosquera-Losada MR, den Herder M, Graves A, Palma JHN, Paulo JA, Pisanelli A, Smith J, Moreno G, Garcia de Jalon S, Varga A, Pantera A, Mirck J, Burgess PJ (2018) Farmers' reasoning behind the uptake of agroforestry practices: evidence from multiple case-studies across Europe. Agrofor Syst. https://doi.org/10.1007/s10457-0170139-9

Santiago-Freijanes JJ, Rigueiro-Rodríguez A, Aldrey JA, Moreno G, den Herder M, Burgess PJ, Mosquera-Losada MR (2018) Understanding agroforestry practices in Europe through landscape features policy promotion. Agrofor Syst. https://doi.org/10.1007/s10457-018-0212-z

Seddaiu G, Bagella S, Pulina A, Cappai C, Salis L, Rossetti I, Lai R, Roggero PP (2018) Mediterranean cork oak wooded grasslands: synergies and trade-offs between plant diversity, pasture production and soil carbon. Agrofor Syst. https://doi.org/10.1007/s10457-018-0225-7

Tsonkova PB, Mirck J, Böhm C, Fütz B (2018) Addressing farmer perceptions and legal constraints to promote agroforestry in Germany. Agrofor Syst. https://doi.org/10. 1007/s10457-018-0228-4

United Nations (2015) Transforming our world: the 2030 Agenda for sustainable development. Resolution adopted by the General Assembly on 25 Sep 2015. http://www.un.org/ga/ search/view_doc.asp?symbol=A/RES/70/1\&Lang=E

Valinger E, Berg S, Lind T (2018) Reindeer husbandry in a mountain Sami village in boreal Sweden: the social and economic effect of introducing GPS collars and adaptive forest management. Agrofor Syst. https://doi.org/10.1007/ s10457-018-0249-z

Westaway S, Kling C, Smith JA (2018) A comparison of the performance of three sward mixtures sown under trees in a silvopoultry system in the UK. Agrofor Syst. https://doi. org/10.1007/s10457-017-0142-1 